\title{
ПІДЛЯСЬКА ЛІТЕРАТУРНА МІКРОМОВА В ПОТРАКТУВАННІ ЯНА ТА ОЛЕКСАНДРА МАКСИМЮКІВ
}

\author{
Кичан Д. О. \\ магістрантка факультету філологї̈ та журналістики \\ Волинський національний університет імені Лесі Украӥнки \\ вул. Винниченка, 30А, Луиьк, Украӥна \\ orcid.org/0000-0002-5144-3755 \\ diana@gmail.com
}

\begin{abstract}
Ключові слова: Підляшия, підляська літературна мікромова, «своя» мова, підяський діалект, західнополіський діалект, кодифікаиія.
\end{abstract}

\begin{abstract}
Запропоновано критичний аналіз концепції Яна та Олександра Максимюків щодо статусу літературної мікромови, яку вони пробують створити на основі підляських говірок, поширених на північно-західній окраїні етнічної української території, що нині входить до складу Республіки Польща.

Специфіка дослідження передбачає виконання таких завдань: визначення й осмислення аргументів на користь тези про окремішність так званого підляського говору, його належність до українського діалектного континууму чи до інших мов; з'ясування кодифікованих Яном Максимюком диференційних особливостей підляської літературної мікромови, зокрема розрізнення природних підляських лінгвальних явищ та штучних нововведень; порівняння прописаних особливостей підляської літературної мікромови з рисами інших українських говорів та літературним варіантом української мови.

Дослідження було здійснено з використанням таких методів лінгвістичного аналізу: спостереження (з метою вирізнення ключових тез проаналізованої концепції), описового (задля характеристики мовних особливостей підляської літературної мікромови), порівняльного (зіставлення кодифікованих ознак новоствореної літературної мікромови з ознаками українських діалектів із метою встановлення їхньої спорідненості). Проведене дослідження дало змогу з'ясувати, що Ян та Олександр Максимюки створили варіант літературної мікромови на основі підляських говірок та кодифікували його у своїх публіцистичних есеях, розміщених на сайті Swoja.org, та в книзі Яна Максимюка «С̆om ne po-swojomu?». Водночас вони заперечили наявність у підляському говорі північноукраїнської, зокрема західнополіської, основи. Автори концепції створили латинський варіант алфавіту, увівши специфічні графеми на позначення деяких фонем, зокрема дифтонгів. Ян Максимюк фрагментарно здійснив аналіз фонетичних та морфологічних особливостей підляських говірок у протиставленні до ознак сучасної української літературної мови. Автор не виконав повноцінного добору прикладів для ілюстрації історико-типологічних рис української мови, не взяв до уваги релевантних явищ багатьох інших українських діалектів, які свідчать про їхню спорідненість із підляськими говірками.
\end{abstract}




\title{
PODLASIAN LITERARY MICROLANGUAGE IN THE INTERPRETATION OF JAN AND OLEKSANDR MAKSYMYUKS
}

\author{
Kychan D. 0. \\ Master's Student at the Department of Philology and Journalism \\ Lesia Ukrainka Volyn National University \\ Vynnychenka str., 30A, Lutsk, Ukraine \\ orcid.org/0000-0002-5144-3755 \\ kychan.diana@gmail.com
}

Key words: Podlasie, Podlasian literary microlanguage, «own» language, Podlasian dialect, West Polissian dialects, codification.
The study is devoted to the analysis of the Jan and Maksymyuk's concept on determining the status of the Podlasian dialect as a literary microlanguage. Podlasian dialect is widespread in the north-western ethnic Ukrainian territory and this is part of the Republic of Poland nowadays.

The specificity of the study involves the following tasks: determining the arguments in favor of the thesis about separation of the Podlasian dialect and the denial of its origin from the basis of other languages; clarification of the differential linguistic features of the Podlasian literary microlanguage and artificial innovations in the literary form of the Podlasian dialect, which were codified by Jan Maksymyuk; comparison of the prescribed Podlasian literary microlanguage's linguistic features with the dialectal peculiarities of the Ukrainian language and the literary form of the Ukrainian language. The research was carried thought with using the following methods of linguistic analysis: observation (in order to distinguish significant theses of the analyzed concept), descriptive (to characterize the linguistic features of Podlasian literary microlanguage), comparative (comparison of codified features of newly created literary microlanguage with features of Ukrainian dialects).

The study revealed that Jan and Oleksandr Maksymyuk created their own version of the literary microlanguage on the basis of Podlasian dialects and codified it in their journalistic essays which were posted on Swoja.org and in Jan Maksymyuk's book "Čom ne po-swojomu?". At the same time, authors denied the existence of a West Polissian dialectal basis in the Podlasian dialect. The authors of the concept created their own Latin version of the alphabet, which introduce specific graphemes to denote some phonemes, including diphthongs. Jan Maksymyuk fragmentarily analyzed the phonetic and morphological features of the Podlasian dialect in contrast to the features of the modern Ukrainian literary language. The author did not make a full selection of examples to illustrate the linguistic features of the Ukrainian language and did not take into account the dialectal features of the Ukrainian language, which indicate affinity with the Podlasian dialects.
Постановка проблеми. Підляшшя - північнозахідна українська етнічна територія, розділена річкою Західний Буг на дві частини - Північне Підляшшя та Південне Підляшшя. Північне Підляшшя нині становить територію Підляського воєводства Республіки Польща. Упродовж століть ця територія опинялася у володіннях Литовської держави, Речі Посполитої, Російської імперії, Польщі, а в часи Другої світової війни - у німецькій окупації. Складні історичні обставини розвитку, що супроводжувалися численними іноземними впливами, спричинили труднощі із самоідентифікацією місцевого населення.

Проблемним є і мовне питання. Мешканці Підляшшя для означення мови, яка поширена в їхньому ареалі, використовують поняття «своя мова», а питання про основу цієї мови дискусійне. Разом із тим спостережено наполегливі спроби створити літературну підляську мову на основі наявних на цій території говірок. Василь Німчук пояснює причини подібного процесу так: «Відчуття соціально-мовного дискомфорту без материнського діалекту, прагнення зберегти його як знаряддя спілкування між відповідними великими чи меншими групами населення певної території, намагання використовувати говір як засіб самовираження та самоідентифікації, інстинктивне побоювання втратити його, намагання оберегти його від занепаду та зникнення може мати різні вияви - 
від принципового вживання діалекту (говору) в спілкуванні зі «своїми» на малій батьківщині і в говірковому чи національному літературно-мовному середовищі до вимоги надання діалектові статусу окремішньої літературної мови або близького до літературно-писемного» [2, с. 21].

Ідею кодифікувати підляську літературну мікромову запропонував Ян Максимюк [1].

Мета статті - аналіз спроб кодифікації підляської літературної мікромови Яном та Олександром Максимюками.

Виклад основного матеріалу дослідження. Ян Максимюк - журналіст, перекладач, уродженець села Ляхи, що на Підляшші. Живе в Чехії, працює на радіо «Вільна Європа» в Празі. Перекладає білоруську літературу польською мовою та тексти декількох європейських літератур білоруською мовою. Активно популяризує писемний варіант підляської мови, створив проєкт літературної «своєї мови», здійснивши, зокрема, спробу укласти правопис і граматику.

Олександр (Алік) Максимюк - брат Яна Максимюка; народився в Білостоці (Польща). Живе в рідному місті, працює програмістом. На прохання брата він створив сайт Swoja.org із метою популяризації новоствореної підляської літературної мови. Олександр Максимюк зазначив [4], що вважає сайт більшою мірою братовим, аніж своїм, оскільки його завдання - це переважно технічне обслуговування сайту. Більшість матеріалів надає Ян Максимюк, який і створив проєкт підляської граматики та словника, представлений на цій інтернет-сторінці.

Окрім цього, до 500-літття Підляшшя (Підляського воєводства) 2014 року Ян Максимюк видав книгу під назвою «Čm ne po-swojomu?», до якої увійшли есеї автора, написані підляською говіркою, деякі - білоруською мовою, а також елементи проєкту правопису, підляський розмовник, словник приказок та прислів їв тощо. Автор уважав за необхідне створити книгу на кшталт антології текстів із сайту з нагоди видатної історичної події, щоб укотре привернути увагу тутешнього населення до актуальних у зазначеному лінгвоареалі мовного та культурного питань.

Брати Максимюки виявили намір зберегти «свою мову», запобігти іiі потенційному зникненню, до чого може призвести інтенсивна полонізація та нечітка етнічна самоідентифікація мешканців Підляшшя. Здійснення такого завдання, на думку авторів сайту, можливе тільки шляхом популяризації та поширення автентичних текстів у письмовій кодифікованій формі. «Ten serwis jest poświęcony normalizacji $i$ rozwojowi nowego wschodniosłowiańskiego języka pisanego - podlaskiego. Jego dialektami mówi około 50000 ludzi we wschodnim regionie
Polski, zwanym Podlasiem (oraz prawdopodobnie 500000 ludzi na Białorusi $i$ Ukrainie, ale ta liczba jest na razie niepotwierdzona). [...] Strona szczéśliwie przetrwała 10 lat, pęczniejąc stopniowo od nowych tekstów w języku polskim, białoruskim $i$ podlaskim, których celem nadrzędnym była wtaśnie gramatyczno-ortograficzna standaryzacja dialektów wschodniostowiańskich pomiędzy Narwia $i$ Bugiem na Podlasiu $i$ wprowadzenie do uzytku publicznego języka podlaskiego jako nowego narzędzia porozumiewania się w mowie i piśmie» [4].

Ян та Олександр Максимюки стійко дотримуються думки, що підляська мова, яку, на їхню думку, складають декілька діалектів, - окрема самобутня незалежна мова, та заперечують походження ії від інших мов: «Do niedawna uważano, że ci ludzie postuguja się peryferyjnymi wersjami języka białoruskiego lub ukraińskiego, w zależności od tego, do której z tych narodowości siebie zaliczają. My jednak twierdzimy, że te dialekty należa do zupetnie odrębnego języka, który zastuguje na ujednolicona i spójna formę zapisu oraz solidne wsparcie...» [4].

Брати Максимюки стверджують, що тільки в разі створення літературної форми тутешньої мови та закріплення ㄲï на письмі буде можливим збереження підляської говірки. На їхню думку, один із важливих кроків для досягнення такої мети - введення латиниці. Ян Максимюк назвав латинський алфавіт ліками, що можуть врятувати мову, яка на межі вимирання. «Alfabet jest oczywiście ważny, ale skoro coraz więcej młodych ludzi na Białostocczyźnie traci nawyk czytania cyrylicy, to należy przyjąc rozwiązanie praktyczne, które ma przyszłość. [...] nie mamy znaczacej historii pisania po pudlasku cyrylica, bo i samych tekstów jest tyle, co kot napłakat» [4, c. 69].

Ян Максимюк не вважає тенденцію до використання латиниці на письмі новою, більше того, називає це явище традицією, яка бере початок від «Mužyćkoji pravdy» Кастуша Каліновського і має вже 150-річну історію [4]. Автор ідеї створення літературної підляської мови почав писати латиницею 2004 року. Тоді ж він зіштовхнувся із проблемою графічного відображення специфічних фонем, характерних для підляських діалектів, адже в латиниці, наприклад, немає відповідних графем для позначення дифтонгів.

У результаті процесу витворення графічної системи літературної підляської мови Ян Максимюк запропонував варіант алфавіту, який містить латин-

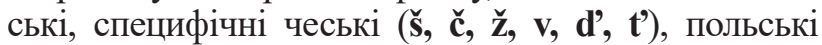
(ś, ć i ź) графеми та новостворені ô i ê (iê) для позначення дифтонгів. Аргументував автор свою логіку так: «Istniêła vže velmi eleganćka grafika z čeśkimi

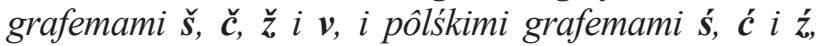
tomu grafemy dla našych dyftonguv nasovuvalisie sami soboju - $\hat{\boldsymbol{o}} i \hat{\boldsymbol{e}}(\boldsymbol{i} \hat{\boldsymbol{e}})$ - bo vony ,estetyčno" pasovali 
do š, č $i$ z. Ja dodav tôlko d' i t' (tože z čeśkoji movy), bo takich zvukuv ne było v literaturnuj biłoruśkuj movi. I vsio. Ja, tak skazati, ušanovav tradyciju (150-liêtniu) i skazav vyrazno, što koli traktovati pisanu pudlaśku jak novu literaturnu movu, to jeji alfabet povinion na vyhlad odličatisie od alfabetuv inšych literaturnych movuv» [4].

На нашу думку, такий варіант графічної системи новоствореної підляської літературної мови надміру штучний, ускладнений.

По-перше, поєднання елементів графіки декількох мов та вигадування нових графем явище незакономірне та непослідовне. Окрім того, не зовсім зрозумілою видається мотивація деяких алфавітних новацій: критерій «естетично пасувати до інших фонем» не $\epsilon$ науково обгрунтованим, тому не може бути підставою для введення такої графеми. Очевидно, автор керується власними суб'єктивними вподобаннями, а не лінгвістичними закономірностями.

По-друге, ключовою метою подібних нововведень було цілеспрямоване вирізнення алфавіту підляської літературної мікромови 3-поміж сусідніх, а не власне графічна необхідність. У контексті цього аргументу погоджуємось із висновком Григорія Аркушина, який має сумніви щодо доцільності переходу на латиницю і наголошує на тому, що «кожен творець нової писемної мови додає щось своє у пропонований алфавіт», аби він тільки відрізнявся від українського та білоруського [3, с. 188]. Для підтвердження цієї тези мовознавець слушно покликається на тезу Василя Німчука: «Для запису українського діалектного мовлення не треба вигадувати правила орфографії, відмінні від нормативних. Коли ж у діалекті є фонеми, відсутні в літературній мові, доцільно використовувати знаки (літери), що їх вживають фахівці для записів українських говіркових текстів» [5, с. 22].

Ідея створити латинський алфавіт для підляської літературної мікромови, на нашу думку, містить внутрішне протиріччя. Брати Максимюки, як і значна частина мешканців Підляшшя, ідентифікують себе як білоруси. Проте вони переконані, що їхня «своя мова» не базується на жодній іншій мові, а є окремою і має статус регіональної або мікромови.

Ян Максимюк підготував чимало есеїв, що стосуються лексичних, фонетичних, морфологічних, орфоепічних та орфографічних особливостей літературної підляської мови, яку він, власне, цим і планував унормувати. Автор умістив ці тексти в п’ятому розділі книги «Čom ne po-swojomu?» під назвою «Hramotno». Характерна особливість згаданих есеїв - те, що написані вони підляською мовою, латиницею (а саме варіантом алфавіту, запропонованим Яном Максимюком), за нормами правопису, які прописано в цьому проєкті. Простежено там також і спроби описати відмінності підляської літературної мікромови від української з метою утвердження концепції про окремішність «своєї мови» та заперечення іiі північноукраїнської основи. Автор акцентує увагу на найменших відмінностях у мовах, не беручи до уваги факту, що порівнює особливості підляської говірки $з$ рисами української літературної мови. Водночас він не згадує про наявність численних українських діалектів та говірок, серед яких ключовим у зазначеному контексті є західнополіський діалект. Григорій Аркушин зауважує: «Підляські говірки тісно лучаться 3 усією україномовною територією, але насамперед із берестейськими та волинсько-поліськими, тому вважаємо їх частинкою західнополіських, хоч, звичайно, вони мають і певні специфічні риси (насамперед у фонетиці це збереження дифтонгів, які вже іншими західнополіськими групами говірок утрачені) [3, с. 173]». А якщо дотримуватися логіки Яна Максимюка в порівнянні української та створеної ним літературної підляської мови, то можна дійти дивного висновку, що цілий ряд українських діалектів не належить українській мові.

Варто відзначити, що Ян Максимюк не бере до уваги особливостей тих декількох говірок, які вирізняють у межах підляського діалекту, а подає вибрані форми, кодифіковані ним. Українські ж діалекти зберегли деякі архаїчні особливості, що не властиві сучасній українській літературній мові.

В есеї під назвою «С́ym raznitsie pudlaśka mova od ukrajinśkoji?» серед аргументів на користь тези про відмінність підляської мови від української Ян Максимюк подає такі фонетичні особливості:

- відсутність звука [p']: «V ukrainśkuj movi je odna spuvzvukova fonema, kotoroji nema $v$ pudlaśkuj - $<\boldsymbol{r}>>$ (Різдво, рішити, рябий, - Ruzdvo, ryšyti, raby) [1, с. 180]. [...] Mjahki zvuk [r'], kotory v ukrajinśkuj movi reprezentuje osôbnu fonemu $\langle\boldsymbol{r}$ '>, vystupaje ne tôlko pered [i], ale i pered [a], [u], [o] (зоря, порядок, грюкати, варю, трьох)» [1, с. 181]. Варто зазначити, що у волинсько-поліських говірках частіше функціонує твердий $[p]$, а не відповідний йому м'який, про що пише Григорій Аркушин: «У всіх 3Х-пол. говірках м'який звук [p'] замінений його твердою парою (буває лише по декілька винятків): бу́ра, бура́к, пора́док, радо́к, на двори́ та ін.», - хоч і про повну відсутність [р'] у певних говірках не йдеться [2, с. 63];

- відсутність явища ікавізму: «U pudlaśkuj movi nema zjavy ikavizmu (zmiêny davnioho jat' $i$ etymolog ičnych e i o $v$ i) u pryzvučnuj pozyciji. U nерryzvučnuj pozyciji v pudlaśkuj movi ikavizm vystupaje velmi rêdko, bo vôn môcno obmežovujetsie nepryzvučnym u abo inšymi samozvukami (e, o)» [1, c. 180]. Подаючи такий аргумент, Ян Максимюк обирає випадкові слова, не покликаючись на статистичні дані та 
будь-які дослідження: «Pryktady na brak ikavizmu v pryzvиспnиј роzусіji: kôń (кінь), liês (ліс), zôrka (зірка), и seliê (в селі), и пос̌е̂ (в ночі). Prykłady na brak ikavizmu $v$ nepryzvučnych pozycijach: kámeń (камінь), pudnestí (піднести), пис̌liêh (нічліг), kunéć (кінець), odktásti (відкласти). Pryktady na vystupanie rêdkoho ikavizmu $v$ nepryzvučnych pozycijach: pisók (пісок), bilíti (білити), svitíti (свiтити)» [1, с. 180]. Натомість Григорій Аркушин, провівши відповідне дослідження, дійшов такого висновку: «Зведена статистика континуантів *е̌ у сучасних підляських говірках (за збірником «Голоси з Підляшшя») така: і виявлено у 105 словах, дифтонг - у 44, и - у 49, тобто безперечна перевага українських континуантів; білоруський рефлекс 'е лише у 42 словах, частину з яких вважаємо запозиченнями з білоруської літературної мови» [2, с. 60];

- твердість шиплячих у всіх позиціях;

- відсутність подовження звуків [l], [n], [t], [š], [г̌ $],[\check{c}] ;$

- дзвінкі звуки втрачають дзвінкість перед глухими;

- активніше функціонування звука [г], ніж в українській мові (у всіх словах, запозичених із грецької та латинської) [1, с. 181].

3-поміж найважливіших морфологічних розбіжностей Ян Максимюк указує такі:

- закінчення -i або -у у прикметниках чоловічого роду, у прикметниках жіночого роду - ненаголошені короткі закінчення -a (-ia) i -e (-ie) або довгі форми наголошені -ája i -óje: «U pudlaśkuj movi prymiêtniki mužčynśkoho rodu kunčajutsie na -i abo -y (matý, biêty, dorohí, dóvhi). V ukrajinśkuj movi prymiêtniki mužčynśkoho rodu kunčajutsie na -ій abo -ий (синій, новий). U pudlaśkuj movi prymiêtniki ženśkoho $i$ serednioho rodu majut abo korotki nepryzvučny kunčatki -a (-ia) $i$-e (-ie), abo dovhi pryzvučny kunčatki -ája i -óje (biêta, dávnia, čórne, vysókie, małája, chudóje). V ukrajinśkuj movi vsiê kunčatki prymiêtnikuv ženśkoho $i$ serednioho rodu korotki, nezaležno od pryzvuku (білий, біла, біле, мали́й, мала́, мале́)» [1, с. 181]. Григорій Аркушин при аналізі особливостей прикметника у волинсько-поліських говірках зауважує: «У ряді говірок східної частини Волинського Полісся у прикметниках чоловічого роду відпадає кінцевий ǐ: до́бри, висо́к'i, зиле́ни, зал'і́зни...» [2, с. 102]. $\mathrm{y}$ прикметниках жіночого та середнього роду спостерігаємо однакові закінчення в підляській та українській літературній мові, проте Ян Максимюк акцентує увагу на тому, що в українській немає нестягнених форм незалежно від наголосу. Це теж сумнівне твердження, адже повні нестягнені форми функціонують в українських фольклорних текстах та в говірках, на чому наголосив і Григорій Аркушин [2, с. 102];

- постфікс -sie, а не -ся у дієсловах;

- «закінчення» -li (pisali, chodili), а не -ли в дієсловах минулого часу множини;

- «закінчення» -uščy, -iuščy, -aščy, -iaščy (rostuščy, smerdiuščy, movčaščy, chodiaščy) в активних дієприкметниках, а не -учий, -ючий, -ачий, -ячий;

- наявність форми двоїни;

- «закінчення»-nie abo -tie (chodiênie, polotie) в іменниках віддієслівного походження, а не -ння, -ття (страчення, биття) [1, с. 181].

У праці «Західнополіська діалектологія» Григорій Аркушин подає зафіксовані ним діалектизми 3 волинсько-поліських та суміжних говірок, які заперечують відсутність в українській мові перерахованих особливостей, зокрема простежено фіналь -лі в дієсловах минулого часу множини: говори́л'i (В 214), говора́л'i (Великі Озера Дубровиць), б'іл'і, прийі́хал'i (В 88), бул'і (В 16) [2, с. 122]; збережено двоїну («Особливістю східної частини західнополіських говірок і перехідних до середньополіських $є$ те, що тут добре збережена двоїна: д'в'і гокн'i, д'ви сил'і, д'ви видри́, три йайщ'i, дв'i сло́в'i та ін.» [2, с. 86].

Висновки. Із метою вирізнення підляської мови з-поміж сусідніх брати Максимюки створили штучний алфавіт, який містить графеми, використовувані в різних мовах. Кодифікуючи нову письмову літературну мову на основі підляських говірок, Ян Максимюк вдається до фрагментарного непослідовного аналізу мовних особливостей «своєї мови», не здійснивши грунтовних лінгвістичних досліджень підляських говірок на всіх мовних рівнях. Аргументуючи тезу на користь окремішності підляської мови, використовує випадкові приклади, на основі яких робить зовсім не переконливі узагальнення про унікальність підляського мовлення, не бере до уваги науково доведених фактів про спорідненість «своєї мови» з говірками волинського та берестейсько-пінського Полісся.

\section{ЛIТЕРАТУРА}

1. Maksimjuk J. Čom ne po svojomu?. Biłostôk : STRUHA EDITIONS, 2014. 306 c.

2. Аркушин Г. Західнополіська діалектологія : навчальний посібник. Луцьк : Волинський нац. ун-т. ім. Лесі Українки, 2012. 257 с.

3. Аркушин Г. Народна лексика західного Полісся : монографія. Луцьк : Східноєвропейський нац. ун-т. ім. Лесі Українки, 2014. 236 с.

4. Веб-сторінка «Swoja.org». URL : https://svoja.org/ (дата звернення: 8 травня 2021). 
5. Німчук В. «Кодифікувати» нові літературні мови? Зберегти й захистити українські говори! Українська мова. 2013. № 3. С. 3-26. URL : http://nbuv.gov.ua/UJRN/Ukrm_2013_3_3 (дата звернення: 7 травня 2021).

\section{REFERENCES}

1. Maksymyuk Y. (2014) Chom ne po svoyomy? [Why not in his own way?]. Bilostock: STRUHA EDITIONS (in Polish, Belorusian)

2. Arkushyn H. L. (2012) Zakhidnopoliska dialektologia [West Polissian dialectology]. Lutsk: Lesia Ukrainka Volyn National University (in Ukrainian)

3. Arkushyn H. L. (2014) Narodna leksyka zakhidnogho Polissya [Folk vocabulary of western Polissya]. Lutsk: Lesia Ukrainka Eastern European National University (in Ukrainian)

4. Webpage «Swoja.org». Retrieved from: https://svoja.org/ (accessed: 8 may 2021)

5. Nimchuk V. V. (2013) "Kodyfikuvaty" novi literaturni movy? Zberehty i zakhystyty ukrayinski hovory! ["Codify" new literary languages? Preserve and protect the Ukrainian dialects!]. The Ukrainian, no. 3, pp. 3-26. Retrieved from: http://nbuv.gov.ua/UJRN/Ukrm_2013_3_3 (accessed 7 may 2021) 